\title{
Sectoral Allocation of Foreign Aids and Poverty Alleviation in Nigeria, 2010-2020
}

\author{
Charles Arinze Obiora \\ Professor of Political Science \\ Chukwuemeka Odumegwu Ojukwu University, Igbariam Campus \\ Anambra State, Nigeria \\ Bonn Obiekwe Godwin Nwanolue \\ Professor of Political Science \\ Chukwuemeka Odumegwu Ojukwu University, Igbariam Campus \\ Anambra State, Nigeria
}

Christian Chidi Okeke (Corresponding author)

Lecturer, Political Science Department

Nnamdi Azikiwe University

Awka, Anambra State, Nigeria

Tel: 234-70-3700-0279Ｅ-mail: co.chidi@unizik.edu.ng

Received: November 6, 2021 Accepted: December 10, 2021 Published: December 16, 2021

doi:10.5296/ijch.v9i1.19389 URL: https://doi.org/10.5296/ijch.v9i1.19389

\begin{abstract}
The study was necessitated by the high rate of poverty in Nigeria regardless of the foreign aids inflow into the country from 2010 to 2020 . Whereas the country received foreign aids which could have resulted in poverty alleviation within the period of this study, she antithetically witnessed increase in poverty rate to the extent that the World Bank in May 2018 reported that Nigeria had emerged poverty capital of the world. According to the National Bureau of Statistics' report, over 82.9 million persons, representing about 40.1
\end{abstract}


percent of the total population, were considered poor by national standards as at 2019 . The poverty challenge inspite of the foreign aids inflow into Nigeria therefore necessitated the question on how sectoral allocation of foreign aids contributed to poverty alleviation in Nigeria from 2010 to 2020. Anchored on the Big Push Theory, the study adopted ex-post facto research design and documentary method for data collection. Qualitative descriptive method was used for data analysis. Among other things, the study found out that sectoral allocation of foreign aid resources did not contribute to poverty alleviation in Nigeria from 2010 to 2020 as those sectors critical for poverty alleviation did not receive massive investments. On the contrary, the foreign aids were split among numerous (consumption) sub-heads which rendered the aids incapable of contributing to poverty alleviation in the country. In view of the findings, the study therefore recommended the need to channel future foreign aids inflow into projects with high capital returns or the productive sectors of the economy in order to achieve a positive outcome on poverty alleviation.

Keywords: poverty alleviation, productive sectors, aid inflow, sectoral allocation, foreign aids

\section{Introduction}

There is consensus among scholars that foreign aids have become imperative in global affairs, particularly in developing countries like Nigeria where lack of capacity and financial resources to fund development programmes remains a perennial challenge for economic development and in pulling citizens out of the vicissitude of poverty. On the other hand, success of the sustainable development goal agenda of the United Nations in Africa, particularly the first goal on ending poverty, depends on the effectiveness of foreign aids (Duru et al., 2020; Pacifique, 2017; United Nations, 2015). That is why elimination of poverty is currently a key concern of all those interested in the development of poor countries to the extent that in official discourse by the World Bank and major donors, for instance, almost every policy is presently assessed in relation to its impact on poverty (Ruggeri et al., 2003).

That Nigeria is an aid recipient is no longer news. She was among Africa's top ten aid recipients (Organization for Economic Cooperation and Development, 2019). In the same way, Nigeria's poverty plague is of international recognition. She presently hosts the largest population of global poor (World Bank, 2019). However, an often astonishing paradox in the discourse on Nigeria's high poverty rate centres on the inability of the foreign aids received by her over the decades to alleviate the poverty scourge. This failure has generally attracted the attention of scholars. Literature abounds on various reasons for the poor impact of aids on poverty. However, there is a dearth of literature on how the foreign aid resources have been allocated over time as well as how this may have accounted for the troubling failure of foreign aids in the country. This necessitated the compelling need to undertake a study on how sectoral allocation of aids has contributed to poverty alleviation in the country, particularly from 2010 to 2020 or not. Filling this gap in literature was the task which this study set out to achieve. It therefore examined the sectoral allocation of foreign aids in Nigeria within the period covered by the study vis a vis the implication of such allocation on 
poverty alleviation in the country.

\subsection{Statement of the Problem}

The failure of Foreign aids to positively impact on poverty alleviation in Nigeria has generated such distress that news on more aids by foreign donors to the country is presently received by majority of the citizens with mixed feelings. In fact, the vast majority of citizens are specifically critical about the disappointing performance of foreign aids in serving as solution to the poverty problem (Ojo et al., 2016; Todaro \& Smith, cited in Ukpong, 2017; Abuzeid, 2009) to the extent that the populace is regrettably forced to accept that foreign aids, in real fact, contribute to the country's troubles, rather than ameliorate them.

However, regardless of the theories on this challenge, the key concern is whether investment of those aids resources are made in sectors that can meaningfully contribute to poverty alleviation or not. This is bearing in mind that Park (2019) had outlined investment in unproductive sectors as part of the negative elements which render aids ineffective in countries. Specifically, investigation into this concern has not been favoured by previous studies done by scholars. In other words, a thorough evaluation of the sectors allocated the foreign aids remains an oft-neglected aspect in the determination of the impact of foreign aids on poverty alleviation in Nigeria. By implication, sectors critical for poverty alleviation in the country could not have received considerable level of investment over the years, if any at all. And the possible lack of attention could have diminished the effectiveness of aids, particularly for poverty alleviation in Nigeria. Interrogating sectoral allocations of foreign aids in Nigeria therefore becomes imperative and is the focus of this study.

\subsection{Objective of the Study}

The objective of this study was to determine how sectoral allocation of foreign aids contributed to poverty alleviation in Nigeria from 2010 to 2020.

\subsection{Research Question}

The study was guided by the following research question:

1. How has sectoral allocation of foreign aids contributed to poverty alleviation in Nigeria from 2010 to 2020 ?

\subsection{Significance of the Study}

The study investigated how sectoral allocation of foreign aids contributed to poverty alleviation in Nigeria from 2010 to 2020 . Strategic allocation of foreign aids to productive sectors of the economy is key to poverty alleviation. This necessitated the study which sought to determine how well Nigeria fared in allocating her aid resources to those sectors that could support poverty alleviation in the country or not. The study is undertaken on this subject area with a view to providing the needed direction in foreign aid usage in the country. The goal is to achieve poverty alleviation. To that end, this study would guide relevant stakeholders in taking as national priority the issue of massive investment of aid into appropriate 
poverty-reduction sectors for better outcome of those aids. Moreso, the study made contribution to the existing body of knowledge by making the aspect that has received scanty scholarly attention its principal focus. The period covered in this study which in itself has received no scholarly attention is novelty to existing knowledge in this field.

\section{Methodology}

The qualitative mechanism of data collection and analysis was applied in this study.

\subsection{Theoretical Framework}

The framework of analysis adopted in this study is the Big Push Theory which argues that to escape the poverty trap and take-off into national development requires a significant inflow of aggregate aid (such as grants and concessional loans) in social and productive sectors which will result in growth across all sectors of poor societies (Shitile \& Sule, 2019). The major proponent of this theory was Paul Narcyz Rosenstein-Rodan. In a 1943 seminar paper titled Problems of Industrialization of Eastern and South-Eastern Europe, Rosenstein-Rodan (1943) observed that unindustrialized countries are characterized by low-level equilibrium trap, difficulty to escape poverty and many small sectors and consequently agreed that the condition justifies the need for foreign aids. The theory, as a strategy, recommends planned, big, large-scale and simultaneous investment programmes in industrialization in order to take advantage of network effects - economies of scale and scope - to escape the low level equilibrium trap (Mahembe \& Odhiambo, 2019; Clunies-Ross et al., 2009; Schleifer, 2009). It puts emphasis on the fact that underdeveloped countries need large investments in order to propel the path of economic progress from contemporary state of backwardness (Umoru \& Onimawo, 2018). In other words, the central tenet of the theory is that only a big and wide-ranging investment package stimulates economic development and as such, definite amount of resources should be dedicated for developmental programs. Accordingly, the theory emphasizes condition for take-off with an argument that a bit-by-bit investment programme will not impact the growth process required for development and escape from poverty.

\section{Literature Review}

\subsection{Foreign Aids, Motivation and Imperativity of Allocations to Productive Sectors}

Many scholars have, over time, offered various perspectives on the concept of foreign aids. Some of the perspectives are, although, incomprehensive and faulty. For instance, Organization for Economic Co-operation and Development (2018) defined the concept as an international development assistance to developing countries from industrialized economies. As in as much as this perspective tries to capture what foreign aids represent, its fault however lies with the insinuation that such international assistance flows from industrialized countries only. That Nigeria, though an unindustrialized economy, has not wavered in committing her resources in ensuring the well-being of her African brothers has been established by Nwanolue and Iwuoha (2012). Another faulty perspective, however, is offered by World Bank (as cited in Abuzeid, 2009) and Association of European Parliamentarians with Africa (2009) which viewed foreign aids as the flow of official financing to the developing world that is 
concessional in character, namely grants and loans with at least a 25 percent grant component. Critical evaluation of their perspective shows that they short-sightedly narrowed foreign aids to grants and concessional loans. Certainly, foreign aids have other forms apart from the two mentioned by the institutions in their definition.

In avid support of this position, Riddell (2007), Ekiring (2000), Okoye (2002) and International Monetary Fund (2003) averred that foreign aids comprise all kinds of resources ranging from physical merchandise, skills and technical know-how, financial grants including gifts, as well as loans which are given to recipients by donors at concessional rates. To them, it equally covers areas such as capital transfers in cash or kind, either as grants or loans; technical assistance and training, usually as grants in the form of human resources and technical equipment, military assistance in the form of either equipment or training advice, free supply of goods and services and food aids. In fact, there could be other emerging forms not captures. That is why it appears safe to say that whatever that should be correctly referred to as foreign aids must unequivocally concede to the fact that foreign aid is an immediate and long-term externally-oriented lifeline, mostly in forms of grants and concessional loans or in kind (with other forms that include project aid, programme aid, technical assistance, humanitarian aid and food aid) from a benevolent buoyant economy, transnational organization or private institutions and persons to a needy recipient for causes that target transforming the prevailing and unacceptable circumstances within the borders and environment of the recipient country.

Obviously, the motivation behind foreign aids is to improve economic development and welfare of less developed countries which are characterized by balance of payment deficits and high levels of debt (Terefe, 2018). In order words, to be considered as foreign aids, the flow must have as its main objective the promotion of the economic development and welfare of developing countries (Association of European Parliamentarians with Africa, 2009). Put differently, the most desired outcome would be that aids help Africans, for instance, to reduce poverty and generate income (Park, 2019). In essence therefore, foreign aids are generally administered with the objective of promoting the economic development and welfare of developing countries by closing the financing gap that otherwise leaves them stuck in a poverty trap and through that achieve reduction in global poverty (Abuzeid, 2009; Schabbel, 2007; Hermias and Kharas, 2008; Burnside and Dollar, 2000; Mahembe and Odhiambo, 2018; Woldekidan, 2015; Olofin, 2013; Ogundipe et al., 2014). In fact, the World Economic Forum in 2005 encouraged developed countries and foreign aid donors to implement the Big Push approach that combines a big increase in foreign aids, investment in employment-creating and welfare sectors, as well as complementary policy change package (Easterly, 2006; Sachs, 2005).

The implication from the last perspective is what Odusanya et al. (2011) emphasized upon when he stated inter alia that foreign aids can have positive effect on economic growth of developing countries through public expenditure if properly channeled to the productive sectors of the economy. What this means therefore is that channeling foreign aids to non-productive or consumption sectors can produce clear opposite effect. To affirm this, Shitile and Sule (2019) drew attention towards using foreign aids to actualize human capital development, by implication, channeling of aids towards human capital development. Moyo 
and Mafuso (2017) in highlighting the culpability of endogenous factors in the whole saga of foreign aids failure, contended that foreign aids to Africa have generally benefited the ruling elites, enabling and perpetuating corrupt governments' hold on power and instigating conflicts and loss of policy independence. As a way out, Riddell (2007) and McCann and McCloskey (2009) suggested the need to prioritize projects that should benefit from foreign aids.

\subsection{The Poverty Debacle in Nigeria}

Noticeably, there is a paradox associated with economic growth in Nigeria in the sense that as the country gets richer, only a few benefits and the majority continues to suffer from poverty and deprivation (Oxfam, 2017). That is to say that the poverty situation in Nigeria is so bad and paradoxical to the extent that a higher proportion of Nigerians continue to live in poverty despite the enormous growth of Nigerian economy on annual basis (Kale, 2012). This means that the economy has failed to lift millions of Nigerians out of poverty. As National Bureau of Statistics (2010) puts it, the proportion of Nigerians living in poverty is increasing every year despite the fact that Nigerian economy is paradoxically growing. On the other hand, poverty is an obstacle or limitation to economic growth in Nigeria (Omoniyi, 2018).

Obviously, Nigeria hosts more of the world's extreme poor today than any other country despite being a lower-middle income country that is large and richly blessed (World Bank, 2019). The situation is so that that World Bank (2019), Dangana (2011) and Asogwa \& Okoli (2008) identified that poverty in Nigeria has remained high, ravaging, real and pervasive despite the economic growth. 40.1 percent of total population in Nigeria was classified as poor. On average, 4 out of 10 individuals in Nigeria have real per capita expenditures below $\mathrm{N} 137,430$ per year and this translates to over 82.9 million Nigerians who are considered poor by national standards (National Bureau of Statistics, 2020). As things stand, there is no indication that the rate is slowing. Even World Bank (2019) believes that Nigeria's extreme poverty rate is increasing, and not decreasing. Nigeria presently is home to the largest number of extremely poor people, overtaking India in 2018, measured at international poverty line of US\$1.90 per day (World Bank, 2018). By projection, the share of Nigeria's population living in extreme poverty will have risen from 42.8 percent (in 2016) to 45.0 percent by 2030, representing about 120 million people living on less than US\$1.90 a day (World Bank, 2019).

\subsection{Sectoral Allocation of Foreign Aids and Poverty Alleviation in Nigeria}

Obviously, poverty is a multidimensional issue which requires strategies that are equally multidimensional, with a focus on emancipation of the poor through relevant sectors of the economy (Taiwo and Agwu, 2016). That, undoubtedly, is what Sachs (cited in Gorius, 2017) had in mind when he contended that poverty could be eliminated globally by the year 2025, thanks to well-placed development aids. By well-placed development aids, he places emphasis in investing development aids into projects with high capital return. That is what Oxfam (2017) attempted to highlight when it insisted that poverty and inequality in Nigeria are not due to lack of resources but to the ill-use and allocation of such resources while Murshed and Khanaum (2014) advised that governments should divert a large portion of aid to investment in the desired sector of an economy, bearing in mind that well-targeted aid 
increases the ability of the poorer country to ensure that the poor have the ability to contribute in achieving growth. Furthermore, they contended that if foreign aids contribute to any productive consumption, they result in a net benefit to economic performance. The question is, how was this true in Nigeria from 2010 to 2020? Table 1 presents donor commitments by sectors from 2011 to 2015.

Table 1. Donor commitments by sectors, $2011-2015$

\begin{tabular}{|c|c|c|c|c|c|}
\hline \multirow[t]{3}{*}{ Sector } & 2011 & 2012 & 2013 & 2014 & 2015 \\
\hline & Committed & Committed & Committed & Committed & Committed \\
\hline & (USD) & (USD) & (USD) & (USD) & (USD) \\
\hline Unspecified & $1,299,180$ & $6,876,000$ & $400,000,000$ & $120,430,341$ & 182,189 \\
\hline Unallocated & $292,843,265$ & $278,500,000$ & $19,475,000$ & $1,572,641$ & $59,083,350$ \\
\hline Administrative Cost & NA & NA & NA & NA & NA \\
\hline Advocacy \& Campaigns & NA & NA & NA & 51,708 & 47,346 \\
\hline Agriculture & $21,992,129$ & $12,866,002$ & $8,565,380$ & $51,914,525$ & $2,731,075$ \\
\hline Basic education \& Gender & NA & NA & NA & 9,710 & NA \\
\hline \multicolumn{6}{|l|}{ Equality } \\
\hline Child Protection & NA & $5,664,361$ & NA & NA & 69,993 \\
\hline Civil Society & NA & 78,210 & 45,993 & $3,319,929$ & 8,330 \\
\hline Combating & NA & NA & NA & NA & NA \\
\hline \multicolumn{6}{|l|}{ Trafficking } \\
\hline Contingency & NA & NA & NA & NA & NA \\
\hline Education & NA & $10,832,850$ & $69,549,781$ & $3,319,929$ & $134,559,462$ \\
\hline Electoral Process & NA & $19,100,000$ & NA & NA & NA \\
\hline Energy \& Environment & 206,428 & $164,233,549$ & NA & $15,500,000$ & $2,435,687$ \\
\hline Extractive & NA & NA & NA & NA & 33,278 \\
\hline Finance & $48,300,000$ & NA & NA & $4,003,292$ & NA \\
\hline Gender Equality & 79,715 & 42,197 & NA & 278,040 & 373,473 \\
\hline Gender Justice & NA & 42,197 & NA & 67,707 & NA \\
\hline Governance & NA & 778,858 & $2,450,925$ & 42,709 & 313,609 \\
\hline
\end{tabular}




\begin{tabular}{|c|c|c|c|c|c|}
\hline Governance & NA & NA & NA & 18,336 & 9,068 \\
\hline Government & $13,322,840$ & $69,075,992$ & NA & NA & 8,330 \\
\hline Health & $123,780,564$ & $364,438,404$ & $102,529,695$ & $99,673,815$ & $330,253,470$ \\
\hline Health \& Sanitation & NA & NA & NA & $3,095,685$ & NA \\
\hline Human Rights & $\mathrm{NA}$ & 545,332 & 46,007 & NA & 49,995 \\
\hline Humanitarian & $\mathrm{NA}$ & NA & NA & $3,095,685$ & 60,000 \\
\hline Judicial Reform & NA & $25,000,000$ & NA & NA & NA \\
\hline Livelihoods & NA & NA & $\mathrm{NA}$ & NA & 30,000 \\
\hline Media & NA & NA & NA & NA & NA \\
\hline Migration Management & NA & NA & NA & NA & NA \\
\hline Political System & $5,226,026$ & NA & NA & 9,710 & NA \\
\hline Poverty Eradication & $92,923,856$ & NA & $152,000,000$ & $4,139,712$ & 253,470 \\
\hline Primary Health Care & NA & 934,197 & $4,066,719$ & 246,330 & 253,470 \\
\hline Project Monitoring Unit & NA & NA & NA & 246,330 & 253,470 \\
\hline Public Finance & $12,324,613$ & NA & NA & NA & 8,330 \\
\hline \multicolumn{6}{|l|}{ Management } \\
\hline Social Policy, Advocacy & NA & $16,060,577$ & NA & $1,261,604$ & 275,871 \\
\hline \multicolumn{6}{|l|}{ and Communication } \\
\hline Tax Justice & NA & NA & NA & NA & 5,000 \\
\hline Trade and Investment & NA & $47,500,000$ & NA & NA & $1,125,000$ \\
\hline Water Sanitation and & NA & $47,544,006$ & NA & $155,460,000$ & $17,053,553$ \\
\hline \multicolumn{6}{|l|}{ Hygiene } \\
\hline Women's Empowerment & NA & $37,474,678$ & 199,261 & 279,429 & 254,180 \\
\hline Total & $612,298,616$ & $1,107,587,410$ & $758,928,760$ & $468,037,169$ & $549,731,000$ \\
\hline
\end{tabular}

Source: MBNP (2015) Development Cooperation Report 2015, pp. 87-88. Minor adjustment by researcher in repositioning Total.

The table shows that from 2011 to 2015 , a total of US\$249,317,038 was commitment by donors for poverty eradication in Nigeria even though data for 2012 was unavailable. In 2015, 
only US\$253,470 was committed to poverty eradication. The highest commitment within the period was in 2013 with US\$152,000,000. Commitment to women's empowerment was also low. Only US\$732,870 was committed to women empowerment from 2013 to 2015.

Generally, a total of US $\$ 651,474,256$ commitment from foreign donors was not allocated to sectors in Nigeria from 2011 to 2015. Year 2011 witnessed highest figure unallocated to sectors as it stood at US\$292,843,265. Year 2014 recorded lowest unallocated fund at US\$1,572,641. Curiously, a total of US\$528,787,710 of the commitments from 2010 to 2015 was unspecified. Even at that, sectors which include judicial reform, political system, project monitoring, public finance management, tax justice as well as social policy, advocacy and communication got commitments. But how much disbursements were made to the sectors? Table 2 presents sector disbursements.

Table 2. Sector disbursements, 2011-2015

\begin{tabular}{|c|c|c|c|c|c|}
\hline Sector & $\begin{array}{l}2011 \\
\text { Disbursed } \\
\text { (USD) }\end{array}$ & $\begin{array}{l}2012 \text { Disbursed } \\
\text { (USD) }\end{array}$ & $\begin{array}{l}2013 \text { Disbursed } \\
\text { (USD) }\end{array}$ & $\begin{array}{l}2014 \text { Disbursed } \\
\text { (USD) }\end{array}$ & $\begin{array}{l}2015 \text { Disbursed } \\
\text { (USD) }\end{array}$ \\
\hline Administrative Cost & NA & NA & NA & NA & NA \\
\hline Agriculture & $20,597,340$ & $9,790,457$ & 984,335 & $34,161,876$ & $1,288,402$ \\
\hline Basic Education and & NA & NA & NA & NA & NA \\
\hline \multicolumn{6}{|l|}{ Gender Equality } \\
\hline Child Protection & NA & $5,533,189$ & NA & NA & 33,330 \\
\hline Civil Society & NA & 78,210 & 45,993 & 679,383 & 679,383 \\
\hline Combating & NA & NA & NA & NA & NA \\
\hline \multicolumn{6}{|l|}{ Trafficking } \\
\hline Contingency & NA & NA & NA & NA & NA \\
\hline Education & NA & $10,624,498$ & NA & $2,727,746$ & $31,471,026$ \\
\hline Electoral Process & NA & $5,395,093$ & NA & NA & NA \\
\hline Energy and Environment & 867,780 & 527,050 & 77,632 & $5,700,000$ & 484,957 \\
\hline Finance & NA & NA & NA & $12,862,075$ & NA \\
\hline Gender Equality & 46,355 & NA & NA & 244,902 & 323,238 \\
\hline Governance & NA & 306,493 & 278,888 & $21,990,724$ & 256,992 \\
\hline
\end{tabular}




\begin{tabular}{|c|c|c|c|c|c|}
\hline Government & $1,355,981$ & $12,460,659$ & NA & $37,718,842$ & NA \\
\hline Health & $8,444,243$ & $170,856,464$ & $258,969,937$ & $400,095,420$ & $116,033,842$ \\
\hline Health and Sanitation & NA & NA & NA & NA & NA \\
\hline Human Rights & NA & 230,422 & 201,270 & NA & 39,996 \\
\hline Judiciary Reform & NA & $5,099,472$ & NA & NA & NA \\
\hline Media & NA & NA & NA & NA & NA \\
\hline Migration Management & NA & NA & NA & NA & NA \\
\hline Political System & $1,306,506$ & $1,306,506$ & $1,306,506$ & $1,306,506$ & NA \\
\hline Poverty Alleviation & 80,897 & 42,959 & $4,230,118$ & $2,409,778$ & 929,283 \\
\hline Primary Health Care & NA & 304,378 & $1,327,206$ & 390,577 & 249,900 \\
\hline Project Monitoring Unit & NA & NA & NA & 244,902 & 249,900 \\
\hline Finance & NA & NA & NA & $17,635,332$ & NA \\
\hline \multicolumn{6}{|l|}{ Management } \\
\hline Social Policy, Advocacy & NA & NA & 195,537 & $2,678,527$ & 249,900 \\
\hline \multicolumn{6}{|l|}{ and Communication } \\
\hline Trade and Investment & NA & NA & NA & NA & NA \\
\hline Water Sanitation and & NA & $38,544,006$ & NA & $13,114,299$ & $17,023,936$ \\
\hline \multicolumn{6}{|l|}{ Hygiene } \\
\hline Women's Empowerment & 68,551 & NA & 619,111 & $4,488,192$ & 250,600 \\
\hline Total & $32,767,654$ & $261,099,857$ & $268,236,532$ & $558,449,080$ & $169,564,686$ \\
\hline
\end{tabular}

Source: MBNP (2015) Development Cooperation Report, 2015. Minor adjustment by researcher in repositioning Total.

The table shows that only US\$7,693,035 out of the committed US\$249,317,038 foreign aids (excluding the 2012 unavailable data) was actually disbursed for poverty alleviation in Nigeria from 2011 to 2015. This is extremely low compared to Government that got disbursement of a whooping US\$51,535,482 despite the unavailable data for 2013 and 2015, Governance at US\$22,833,097 (without 2011 data) as well as Finance whose available data for 2014 stood at a whooping US\$12,862,075. Even Electoral Process and Judiciary Reform in 2012 alone got disbursements of US\$5,395,093 and US\$5,099,472 respectively. The disbursement for Electoral Process in 2012 at USD\$5,395,093 was higher than that for 
Women's Empowerment which got US\$5,357,903 from 2013 to 2015. With this development, can one say that foreign aids flow into Nigeria was aligned with national priorities, particularly poverty alleviation?

\subsection{Strategic Alignment of Aids Inflow into Nigeria with National Development Priorities/Poverty Alleviation: Matters Arising}

Ordinarily, the expectation was that foreign aids significantly bridge financing and foreign exchange gaps, improve human and technological capacity, fill infrastructural gaps, create jobs and improve living standards as a way to accommodate a growing number of young people entering the labour market by creating at least 5 million new jobs each year over the next decade (International Monetary Fund, 2021b). This expectation is hinged on the fact that developing countries just like Nigeria do not have enough industrial base and are characterized by low human development, therefore making foreign aids a dominant strategy for reducing their poverty level (Madhusanka, 2021). However, aid is not yet able to contribute significantly to sustainable development in the country (MBNP, 2015).

For Nigeria, expectation was that the development assistance inflows would contribute significantly to meeting the country's national aspirations which include bridging the development gap between the country and her advanced counterparts, poverty elimination, industrialization and significant improvement in socio-economic infrastructure (MBNP, 2015). This was imperative, moreso as the country has one of the lowest revenue levels as a share of Gross Domestic Products worldwide with a large share of revenues spent on the country's public debt service payments thus leaving insufficient fiscal space for critical social and infrastructure spending and to cushion an economic downturn (International Monetary Fund, 2021b).

The practical experience, however, is that aid flows into Nigeria were not aligned with national development priorities within the period under study. Put differently, emphasis in terms of priority and allocation of foreign aid resources was placed on areas that are disconnected from national development and in particular poverty alleviation. This lacuna is what prompted Forster (2020) to sound a note of hope to the effect that in Nigeria, an opportunity exists: an opportunity to build on 60 years of development cooperation, for donors and government to work hand in hand, openly, to ensure that future investment is evidence-based, aligns with national priorities, and that the process, not just the result, helps build confidence and trust all around.

As things stand in Nigeria, numerous donors each with their own procedures, priorities and understanding of the country's needs and constraints exist. Some 200 international non-governmental organizations, about $20 \mathrm{UN}$-related agencies as well as bilateral and multilateral international development partners exist. The consequent effect is that some of their interventions are seen to constitute a distortion in the growth and development process of the Nigerian economy, implying that the country may not be deriving maximum benefits from aid investment (MBNP, 2015).

Paradoxically, sectors which are critical for poverty reduction in the country did not witness 
sufficient or massive investment within the period covered by this study and achieving poverty reduction could not have been realistic in the face of the low disbursements. For instance, it is obvious that a positive outcome with foreign aids remains unrealizable when only US\$7,693,035 out of the committed US\$249,317,038 foreign aids (excluding the 2012 unavailable data) was actually disbursed for poverty alleviation in Nigeria from 2011 to 2015. On the other hand, available data showed that some sectors which could not contribute to poverty alleviation in the country got allocations and higher disbursements for that matter.

In simple term, aid flows into Nigeria were not aligned with national development priorities as emphasis in terms of priority and allocation of foreign aid resources was placed on areas that are disconnected from national development and in particular poverty alleviation. Most of the donors sacrificed national development priorities at the altar of their own procedures, priorities and understanding of the country's needs and constraints (MBNP, 2015).

\section{Findings}

This study made some findings. The primary finding is that sectoral allocation of foreign aid resources did not contribute to poverty alleviation in Nigeria from 2010 to 2020 owing to the fact that sectors critical for poverty alleviation did not receive massive investments. Instead, the foreign aids were split among numerous (consumption) sub-heads which rendered the aids incapable of contributing to poverty alleviation in the country. It also found that the donors' assistance did not flow into national priority sectors (social and productive sectors) to ensure that the aids create effects that benefit poverty alleviation. In fact, there was zero allocation in some cases. For instance, a total of US\$651,474,256 million from aid commitments by foreign donors was not allocated to sectors in Nigeria from 2011 to 2015. 2011 was the year with highest figure unallocated to sectors as it stood at US\$292,843,265 million. Year 2014 recorded lowest unallocated fund at US\$1,572,641 million. Curiously, a total of US\$528,787,710 million of the commitments from 2010 to 2015 was allocated to unspecified sectors. Some of the sub-heads which got allocations were quite irreconcilable with poverty alleviation. The sub-heads which got donor commitments within the period under study even though it was not clear how they could have contributed to poverty alleviation in the country were Advocacy Campaign US\$99,054 thousand (2014 and 2015 data available), Child Protection US\$5,734,354 million (2011 and 2015 data available), Electoral Process US\$19,100,000 million (2011 data available), Finance US\$52,303,292 million (2011 and 2014 available), Gender Equality US\$773,425 thousand (2011, 2012, 2014 and 2015 data available), Gender Justice US\$109,904 thousand (2012 and 2014 data available), Governance (which appeared under double sub-heads with first sub-head covering 2012-2015 US\$3,586,101 million; second sub-head covering 2014 and $2015 \$ 27,404$ thousand) US\$3,613,505 million as well as Government US\$82,407,162 million $(2011,2012$ and 2015 data available).

\section{Recommendations}

In view of the findings, the study therefore made some recommendations. First is that there is the need to channel future foreign aids inflow into projects with high capital returns or the productive sectors of the economy in order to achieve a positive outcome on poverty 
alleviation. That means that external borrowings should neither be used for recurrent expenditures nor consumption purposes but should instead be synchronized into national priorities, poverty reduction serving the topmost purpose. By implication, such aids should be aligned with national development strategies as against the current practice where donors are allowed to apply their discretion in the choice of sectors to benefit what from their assistance and to what extent, without relevant input by national stakeholders.

\section{References}

Abuzeid, F. (2009). Foreign aid and the big push theory: Lessons from Sub-Saharan Africa. Stanford Journal of International Relations, 11(1), 16-23.

Asogwa, F., \& Okoli, P. (2008). Economic crimes and national development. Enugu: Institute for Development Studies.

Association of European Parliamentarians with Africa. (2009). Safeguarding the interest of the people: Parliaments and aid effectiveness. Retrieved August 25, 2020, from www.awepa.org/resources/doc_details/36-safeguarding-the-interests-of-the-people-parliamen tarians-and-aid-effectiveness

Burnside, C., \& Dollar, D. (2000). Aid, policies and growth. American Economic Review, 90(4), 847-868. https://doi.org/10.1257/aer.90.4.847

Clunies-Ross, A. et al. (2009). Development economics ( $1^{\text {st }}$ ed.). Berkshire: McGrow-Hill Higher Education.

Dangana, J. (2011). Building a new Nigeria: The right approach (Vol 3). Kaduna: First Pyramid Digital Publishing Co Limited.

Duru, I. et al. (2020). Foreign aid and economic growth: Empirical evidence from Nigeria. Growth, 7(1), 35-50. https://doi.org/10.20448/journal.511.2020.71.35.50

Easterly, W. (2006). The white man's burden: Why the west's efforts to aid the rest have done so much ill and so little good. New York: Penguin Press.

Ekiring, R. (2000). Impact of foreign aid on poverty alleviation in developing countries: With an application to Uganda, Maastricht School of Management, Netherlands.

Federal Government of Nigeria. (2010). Nigeria poverty profile. Abuja: NBS.

Federal Government of Nigeria. (2015). Cooperation report 2015. Abuja: MBNP.

Federal Government of Nigeria. (2020). Labour force statistics: Unemployment and underemployment report. Abridged labour force survey under Covid-19 Q2 2020. Abuja: NBS.

Forster, G. (2020). What use is aid and development data? Two examples from Nigeria. Retrieved February 6, 2021, from https://reliefweb.int/report/nigeria/what-use-aid-and-development-data-two-examples-nigeria Gorius, L. (2017). How much does it cost to end poverty? Retrieved February 28, 2021, from 
https://borgenproject.org/how-much-does-it-cost-to-end-poverty/

Hermias, J., \& Kharas, H. (2008). Thrive on competition. Retrieved February 25, 2020, from https://www.inwent.org/ez/articles/065249/index.en.shtml

International Monetary Fund. (2003). World economic outlook: Public debt management in emerging markets. Washington, DC: International Monetary Fund.

International Monetary Fund. (2021). IMF executive board concludes 2020 Article IV consultation with Nigeria. Retrieved February 9, 2021, from https:/www.imf.org/en/News/Articles/2021/02/08/pr2135-nigeria-imf-executive-board-concl udes-2020-article-iv-consultation

Kale, Y. (2012). The review of the Nigerian economy. Abuja: National Bureau of Statistics.

Madhusanka, M. (2021). The effect of foreign aids on economic growth of Sri Lanka. International Journal of Innovative Science and Research Technology, 6(1), 114-118.

Mahembe, E., \& Odhiambo, N. (2019). Foreign aid and poverty reduction: A review of international literature. Cogent Social Sciences, 5(1), 1-15. https://doi.org/10.1080/23311886.2019.1625741

McCann, G., \& McCloskey, S. (2009). From the local to the global. London: Pluto Press.

Moyo, L., \& Mafuso, L. (2017). The effectiveness of foreign aid on economic development in developing countries: A case of Zimbabwe (1980-2000). Journal of Social Sciences, 52(1-3), 173-187. https://doi.org/10.1080/09718923.2017.1305554

Murshed, M., \& Khanaum, M. (2014). Impact of foreign aid in the economic development of recipient country. Journal of the Bangladesh Association of Young Researchers, 2(1), 33-37. https://doi.org/10.3329/jbayr.v2i1.20539

Nwanolue, B., \& Iwuoha, V. (2012). A reflection on Nigeria's past: Africa as the centerpiece of Nigeria's foreign policy revisited. Developing Country Studies, 2(4), 76-84.

Odusanya, A. et al. (2011). Foreign aid, public expenditure and economic growth: The Nigerian case. Journal of Applied Business Research, 27, 33-42. https://doi.org/10.19030/jabr.v27i3.4211

Ogundipe, A. et al. (2014). Is aid really dead? Evidence from Sub-Saharan Africa. International Journal of Humanities and Social Science, 4(10), 300-314.

Ojo, O. et al. (2016). The impact of foreign aid on poverty reduction/alleviation programmes in Lagos State, Nigeria. Journal of Research and Development, 2(12), 40-49. https://doi.org/10.12816/0028320

Okoye, O. (2002). Development administration: Theories and applications in Nigeria. Onitsha: Abbot Books Limited.

Olofin, O. (2013). Foreign aid and poverty level in West African countries: New evidence using a heterogeneous panel analysis. Australian Journal of Business and Management 
Research, 3(4), 9-18. https://doi.org/10.52283/NSWRCA.AJBMR.20130304A02

Omoniyi, B. (2018). An examination of the causes of poverty on economic growth in Nigeria. Africa's Public Service Delivery and Performance Review, 6(1), 1-10. https://doi.org/10.4102/apsdpr.v6i1.175

Organization for Economic Co-operation and Development. (2018). Net ODA (Indicator). Retrieved February 17, 2020, from https://data.oecd.org/oda/net-oda.htm

Organization for Economic Co-operation and Development. (2019). The well-being of nations: The role of human and social capital. Paris: OECD.

Oxfam. (2017). Inequality in Nigeria: Exploring the drivers. Retrieved February 12, 2021, from https://www.oxfam.org/en/research/inequality-nigeria-exploring-drivers

Pacifique, M. (2017). Aid, economic growth and poverty: Analysis of the stimulating and distorting effects of official development assistance on Sub-Saharan African countries. An unpublished $\mathrm{PhD}$ Economics Thesis of Universidad de Cantabria.

Park, J. (2019). Re-inventing Africa's development: Linking Africa to the Korean development model. Switzerland: Palgrave Macmillan. https://doi.org/10.1007/978-3-030-03946-2

Riddell, R. (2007). Does foreign aid really work? Oxford: University Press.

Rosenstein-Rodan, P. (1943). Problems of industrialization of Eastern and South-Eastern Europe. The Economic Journal, 53, 202-211. https://doi.org/10.2307/2226317

Ruggeri, L. et al. (2003). Does it matter that we don't agree on the definition of poverty? A comparison of four approaches. Oxford Development Studies, 31(3), 243-274. https://doi.org/10.1080/1360081032000111698

Sachs, J. (2005). The end of poverty: Economic possibilities for our time. New York: Penguin Press.

Schabbel, C. (2007). The value chain of foreign aid: Development, poverty reduction and regional conditions. New York: Springer.

Schleifer, A. (2009). Peter Bauer and the failure of foreign aid. Cato Journal, 29(3), 379-382.

Shitile, T., \& Sule, A. (2019). Reassessing the efficacy of foreign aid and grants in poverty reduction in Nigeria. Asian Economic and Financial Review, 9(4), 450-460. https://doi.org/10.18488/journal.aefr.2019.94.450.460

Taiwo, J., \& Agwu, M. (2016). Problems and prospects of poverty alleviation programmes in Nigeria. International Journal of Business and Management Review, 4(6), 18-30.

Terefe, K. (2018). Drivers of economic growth in Ethiopia: Does foreign aid and policy complementarity matter? Journal of Economics and International Finance, 10(8), 95-110. https://doi.org/10.5897/JEIF2017.0866

Ukpong, J. (2017). Foreign aid and African development: Lessons from Nigeria. Journal of 
Political Sciences and Public Affairs, 5(3), 1-3.

Umoru, D., \& Onimawo, J. (2018). National policy and big-push theory of development in Nigeria: Moving away from low-level economic equilibrium, Scientific Papers of Silesian $\begin{array}{llll}\text { University } & \text { of } & \text { Technology, } & \text { 116(1995), }\end{array}$ https://doi.org/10.29119/1641-3466.2018.116.13

United Nations. (2015). Transforming our world: The 2030 agenda for sustainable development. $\quad$ Retrieved November 12, 2020, from https://sustainabledevelopment.un.org/post2015/transformingourworld

Woldekidan, H. (2015). The role of foreign aid in reducing poverty: Time series evidence from Ethiopia. Journal of Economics and International Finance, 7(3), 59-71. https://doi.org/10.5897/JEIF2015.0646

World Bank (2018). In 12 years, 90\% extremely poor will live in Nigeria, other sub-saharan countries, May 2018. New York: World Bank Group.

World Bank. (2019). Advancing social protection in a dynamic Nigeria. New York: World Bank Group.

\section{Copyrights}

Copyright for this article is retained by the author(s), with first publication rights granted to the journal.

This is an open-access article distributed under the terms and conditions of the Creative Commons Attribution license (http://creativecommons.org/licenses/by/4.0/) 